\title{
The cost of grape mechanical harvesting is more economical than the manual harvest?
}

\author{
Fabrício Domingues $^{1, a}$ and Juan Saavedra del Aguila ${ }^{2, a}$ \\ ${ }^{1}$ Miolo Wine Group Vitivinicultura LTDA, Est. Municipal Livramento - Passo da Cruz s/n, Vila Palomas, Santana do Livramento, \\ Rio Grande do Sul (RS), CEP 97573-970, Brasil \\ ${ }^{2}$ Universidade Federal do Pampa (UNIPAMPA) - Campus Dom Pedrito - Curso de Bacharelado em Enologia, Rua Vinte e Um de \\ Abril n ${ }^{\circ}$, Dom Pedrito, Rio Grande do Sul (RS), CEP 96450-000, Brasil
}

\begin{abstract}
The objective of this study was to compare the costs of mechanical harvesting and grape manual in commercial property of "Santana do Livramento", "Rio Grande do Sul" (RS) - Brazil. The study was conducted commercial vineyard, over four years (2013-2016), throughout this period we evaluated 154.9 ha on the mechanical harvesting of grapes and; 366.7 ha on the grapes of manual harvesting; for both types of collection were recorded all costs thereof, including annual fixed fees (depreciation + maintenance), obtaining at the end the amount of crop expressed in real per hectare; also calculated the minimum required area vineyard justify mechanical harvesting. The cost of manual harvesting was $133.3 \%$ higher than the value obtained for the mechanical harvesting the studied time interval. Obtained the area of $41.92 \mathrm{ha}$, as the point of balance between the costs of manual and mechanical harvesting (equivalent costs), above this area (41.92 ha), grape mechanical harvest is economically justified. All conditions tested, it was concluded that preliminary cost per hectare of grape mechanical harvesting is lower than the cost per hectare of manual harvesting and vineyard areas plausible mechanical harvesting exceeding $41.92 \mathrm{ha}$, justify the use of the collection system grape mechanics.
\end{abstract}

\section{Introduction}

The changes that pass the savings induced by globalization have required the agricultural sector increasingly technical and economic efficiency in the conduct of exploration. In this search context of competitiveness, knowledge of production costs and profitability of cultures is increasingly important in the decision-making process of the producer at the time of choosing a particular technology [1].

Grapes for juice and wine industry, there is the possibility of mechanization of the harvest. In New York, the GDC driving system was created, aiming, among other attributes, its suitability for mechanical harvesting. In Europe, the United States and Australia, driving in cordon, mechanical harvesting is already widespread [2].

Harvesting is the removal of the commodity from the parent plant or the removal of the entire plant from the production field if it is the economic commodity [3].

In most countries where the availability of labor is scarce and expensive, it adopts mechanized harvest in vineyards for the production of grapes for winemaking. The adoption of this technology mode is extremely important to elaborate wines can compete both in the domestic market with imported wines, as in the foreign market [1,2].

\footnotetext{
a e-mail: Fabrício.domingues@miolo.com.br; juanaguila@unipampa.edu.br
}

Harvesting method is also of importance to product quality. For fresh consumption, delicate handling is requiered for Premium fruit, as the bloom (waxy covering) of the grape should be preserved. Fruit are hand harvested and placed in protective containers for shipping to market $[2,4]$.

For some wine styles, hand harvesting is a must; for example, for sparkling wine production the fruit needs to be intact before processing starts, or harsh phenolics may be extracted from the rachis and skins. For many wines, however, machine harvesting is acceptable as the breaking of the berry skins and their mingling with the juices helps to extract desired compound [4].

The objective of this study was to compare the costs of mechanical harvesting and grape manual in commercial property of "Santana do Livramento", "Rio Grande do Sul" (RS) - Brazil, between the years 2013 to 2016.

\section{Matherials and methods}

The study was conducted commercial vineyard, located in the city of "Santana do Livramento" - RS, Brazil, over four years (2013-2016), throughout this period we evaluated 154.9 ha on the mechanical harvesting of grapes and system and; 366.7 ha on the grapes of manual harvesting system.

For both types of collection were recorded all costs thereof, including annual fixed fees (depreciation + maintenance), obtaining at the end the amount of crop 


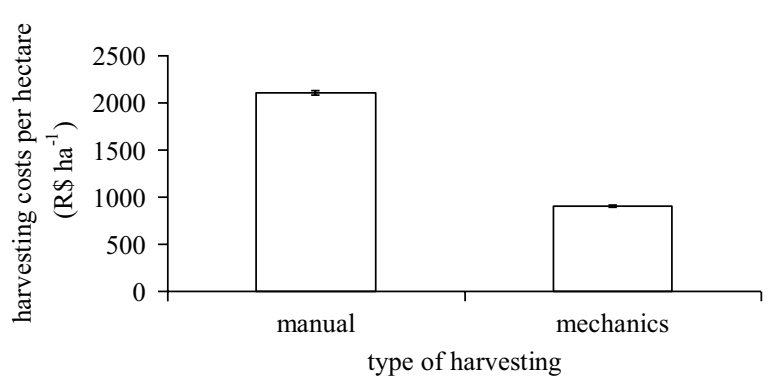

Figure 1. Harvesting cost per hectare $\left(\mathrm{R} \$ \mathrm{ha}^{-1}\right)$ in two different types of grape harvesting (manual and mechanical), these averages were obtained after the monitoring of the total costs of the harvest for a period of 4 years (2013-2016), both types of harvesting. Vertical bars represent the standard error of the mean.

expressed in real per hectare; also calculated the minimum required area vineyard justify mechanical harvesting.

We conducted the variance analysis (ANOVA) and when necessary was applied to the comparison Tukey's test at the $5 \%$ probability [5-7].

\section{Results and discussion}

During the period studied (2013-2016), the total amount of mechanical harvest per hectare expressed in "reais" was significantly less than the total value of the manual harvest per hectare also expressed in "reais", and the cost of manual harvesting was $133.3 \%$ higher than the value obtained for the mechanical harvesting the studied time interval (Fig. 1).

Mechanical harvesting of wine grapes has been commercially practised for some time, and is now an accepted way of obtaining quality grapes at low cost and at any time of day or night. Most reports agree that a wellset-up mechanical harvester will provide fruit quality that is close to that of hand-harvested fruit. Modern equipment with further refinements are now approaching the ability to harvest berries with little or no skin breakage, which may lead to further changes in how the industry preceives the practice [4].

Grape production costs vary according to the driving system, the planting density, the soil, the amount of hand labor, inputs prices, the technology, among others [8].

Most grapes intended for wine are harvested mechanically, although grapes for fine wines may be picked by hand to select for even maturity and to avoid poorquality grapes. For example, mechanical harvesting cannot distinguish between the primary crop and second set crop that may develop on shoot laterals, resulting in a lower-quality must. Thus, in some cases, pickers may go through a vineyard to remove immature or diseaded clusters before mechanical picking. As there is mechanical damage to the fruit during the process, $\mathrm{SO}_{2}$ may be added to the harvesting bin to slow oxidation while the fruit is transported to the winery $[2,4,9]$.

Taking into account the annual fixed cost is diluted with increasing area harvested grape and comparing the total value of mechanical and manual harvests per hectare, obtained the area of 41.92 ha, as the point of balance between the costs of manual and mechanical harvesting (equivalent costs), above this area (41.92 ha), grape mechanical harvest is economically justified.

One advantage of mechanized harvest is that cluster size and position within the canopy is no longer as great a concern, which can lead to greater freedom in developing trellising/training systems. Hand harvesting is most efficient when clusters are large and within a distinct zone in the canopy, but with machine harvesting this does not matter. This lends itself to the adoption of minimal pruning, where mechanization is a great cost and timesaver, and allows for more flexibility in getting the fruit in when it is ready [4].

\section{Conclusion}

All conditions tested, it was concluded that preliminary cost per hectare of grape mechanical harvesting is lower than the cost per hectare of manual harvesting and vineyard areas plausible mechanical harvesting exceeding $41.92 \mathrm{ha}$, justify the use of the collection system grape mechanics.

\section{References}

[1] J.M. Soares, P.C. de S. Leaão, A Vitivinicultura no Semiárido Brasileiro. Brasília, DF, Embrapa Informação Tecnológica, 756p. (2009)

[2] E. Giovannini, V. Manfroi, Viticultura e Enologia, Elaboração de grandes vinhos nos terroirs brasileiros. Bento Gonçalves: IFRS, 364p. (2009)

[3] E.F. Durner, Principles of Horticultural Physiology. Wallingford, UK, CABI International, 405p. (2003)

[4] G.L. Creasy, L.L. Creasy, Grapes. Wallingford, UK, CABI International, 295p. (2012)

[5] F.C. de Almeida; J.F.L. de C. Cham; B.L. Hamm; S.M. Ferreira; M. Gabbardo; J. Saavedra del Aguila. Use of plant growth regulation in the conservation of grapes 'Italy' as aid postharvest, France, Bio Web of Conferences, v. 3 , 4p. (2014)

[6] J. Saavedra del Aguila; A.P. Dachi; E.N. Fernandes; B.L. Hamm; F.C. de Almeida; J.M. Silveira. Garlic and $\mathrm{H}_{2} \mathrm{O}_{2}$ in overcoming dormancy on the vine 'Cabernet Sauvignon', France, Bio Web of Conferences, v. 5 , 3p. (2015)

[7] J. Saavedra del Aguila; A. Zanella; A.D. Pinheiro; A.M. dos Santos; E.B. Radmann; L.S. Heiffig-del Aguila, Woody cuttings of 'Niagara Rosada' and 'Niagara Branca' rustic grapes. Wageningen, Holanda. Acta Horticulturae, v. 1115, p. 249-252 (2016)

[8] J.C. Nachtigal, U.A. Camargo, M.A.F. Conceição, Uvas sem Sementes Cultivares BRS Morena, BRS Clara e BRS Linda. Brasília, DF, Embrapa Informação Tecnológica, 90p. (2004)

[9] E. Giovannini, Manual de Viticultura. Porto Alegre: Bookman, 253p. (2014) 